\title{
Acetylsalicylic acid increases postharvest longevity of ornamental sunflower inflorescence
}

\section{Ácido acetilsalicílico no aumento da longevidade pós colheita de inflorescências de girassol ornamental}

\author{
Ananda Covre da Silva ${ }^{1 *}$; Helio Fernandes Ibanhes Neto ${ }^{1}$; Ricardo Tadeu de Faria ${ }^{2}$; \\ Lúcia Sadayo Assari Takahashi ${ }^{3}$
}

\section{Highlights}

Acetylsalicylic acid (ASA) influences the longevity of ornamental sunflower.

Treatment with $400 \mathrm{mg} \mathrm{L}^{-1} \mathrm{ASA}$ dose provided the longest commercial lifespan.

The dose and time interaction affects the postharvest quality of the floral stems.

\begin{abstract}
Sunflower to be used in ornamental floral arrangements need to be free from damage, and have longer shelf life. The aim of the present study was to evaluate the effect of acetylsalicylic acid (ASA) on the postharvest longevity of ornamental sunflower. Floral stems of the cultivar Vicent's Choice from Sakata Seed were placed in flasks containing $350 \mathrm{~mL}$ of solution containing $0,200,400,600,800$, or $1000 \mathrm{mg}$ of ASA per liter of distilled water. Aspirin ${ }^{\circledast}$ (acetylsalicylic acid) tablets were used as the source of salicylic acid. Grades from 0 to 5 were assigned every day, according to a pre-established criteria for assessing the longevity and quality of the inflorescences. The data were subjected to analysis of variance, Tukey's test ( $t=0.05 \%)$, and regression analysis using Sisvar program. Significant differences were observed in the grades from the sixth to the tenth day of treatment, but not in the total longevity. Treatment with $400 \mathrm{mg} \mathrm{L}^{-1}$ of ASA improved the commercial longevity to an average of 9 days, about 4 days more than the control $\left(0 \mathrm{mg} \mathrm{L}^{-1}\right)$. At 400 $\mathrm{mg} \mathrm{L}^{-1}$ dose, ASA prolongs the commercial longevity and maintains the postharvest quality of ornamental sunflower stems. However, at the maximum dose used $\left(1000 \mathrm{mg} \mathrm{L}^{-1}\right)$, the evaluated parameters did not show any improvement over the controls.
\end{abstract}

Key words: Conservation. Ethylene. Cut flower. Helianthus annus.

1 M.e in Agronomy, University of the State of Londrina, UEL, Centre of Agrarian Sciences, Londrina, PR, Brazil. E-mail: ananda_covre@hotmail.com; helioibanhes@hotmail.com

2 Prof. Dr., Department of Agronomy, UEL, Londrina, PR, Brazil. E-mail: faria@uel.br

3 Profa Dra Senior, Department of Agronomy, Graduate Program in Agronomy, UEL, Londrina, PR, Brazil, Productivity Scholarship from Fundação Araucária. E-mail: sadayo@uel.br

* Author for correspondence

Received: June 04, 2020 - Approved: Mar. 26, 2021 


\section{Resumo}

A utilização do girassol em arranjos florais e ornamentação exige um material de qualidade, livre de danos e com alta durabilidade. O objetivo do presente estudo foi avaliar o efeito da solução conservante de ácido acetilsalicílico na longevidade pós colheita de girassol ornamental. Hastes florais da cultivar Vicent's Choice - Sakata Seed foram padronizadas e alocadas em frascos contendo $350 \mathrm{~mL}$ de solução composta por 0, 200,400,600, 800, e 1000 mg de ácido acetilsalicílico (AAS) por litro de água destilada. Utilizaram-se comprimidos do medicamento Aspirina ${ }^{\circledR}$ (Ácido acetilsalicílico) como fonte de ácido salicílico. Diariamente houve a atribuição de notas de zero a cinco de acordo com tabela pré-estabelecida para avaliação da longevidade e qualidade das inflorescências de girassol. Os dados foram submetidos a análise de variância, teste de Tukey ( $\mathrm{t}=0.05 \%$ ), e análise de regressão com o auxílio do programa Sisvar. Foi possível observar diferenças significativas no critério notas a partir do sexto até o décimo dia de teste. Não houve diferenças significativas para a variável longevidade total, entretanto, quanto à longevidade comercial, o tratamento com $400 \mathrm{mg} \mathrm{L}^{-1}$ se diferenciou dos demais com média de 9 dias, cerca de 4 dias a mais que a testemunha (0 mg L-1). A utilização de solução conservante de ácido acetilsalicílico (400 $\mathrm{mg} \mathrm{L}^{-1}$ ) prolonga a longevidade comercial e a manutenção da qualidade pós-colheita de hastes florais de girassol ornamental quando comparado ao tratamento controle. A utilização da dosagem máximo (1000 $\mathrm{mg} \mathrm{L}^{-1}$ ) não promoveu aumento significativo em comparação com a testemunha para este parâmetro avaliado.

Palavras-chave: Conservação. Etileno. Flor de corte. Helianthus annus.

\section{Introduction}

Success of Brazilian floriculture industry has placed the country among the 15 largest flower producers in the world. With continuous growth over the years, the industry had a turnover of 7.9 billion reais in 2018 (Instituto Brasileiro de Floricultura [IBRAFLOR], 2019).

In this continuously expanding market, the sunflower (Helianthus annum L.) has a high ornamental potential and great acceptability, and can be commercialized as a cut flower as well as in pots (Schoellhorn, Ermino, \& Alvarez, 2003).

From an agronomic point of view, ornamental sunflower production is economically viable due to its drought tolerance, low incidence of pests and diseases, short cycle, sturdiness, and ease of propagation (Zobiole, Castro, \& Oliveira, 2010; Albuquerque, Moro, Fagiole, \& Ribeiro, 2001). In addition, intensive production, with high profitability in small areas, means that the capital invested is quickly recovered, arousing the interest of producers and investors (Oliveira, 2017).

To use the sunflower in floral arrangements and as a vase flower, it necessary to obtain good quality of flowers that are free from damage, and are longlasting. It is common to use cold storage along with preservative and germicidal products to delay senescence, increase the shelf-life, and maintain the quality of cut flowers, fruits, and vegetables (Freddo, Cechim, Mazaro, 2013; Mattiuz, 2005).

Several studies have reported the use of chemicals, such as sodium hypochlorite and 
sucrose, to preserve and maintain the postharvest quality of cut flowers. Silva and Silva (2010) observed lower senescence of the white chrysanthemum stems, with the use of $10 \%$ sucrose solution.

Senescence occurs due to increase in hydrolytic enzymes, degradation of starch and chlorophyll, increased respiration, and enhanced ethylene production (Dukovisk, Bernatzky, \& Han, 2006), resulting in petal abscission, wilting, cellular breakdown, and the growth of microorganisms in the tissues (Finger, Carneiro, \& Barbosa, 2004).

Use of inhibitors of ethylene synthesis and activity, is an option to delay the senescence and increase the postharvest life of flowers and fruits (Porat, Shlomo, Serek, Sisler, \& Borochov, 1995). Due to its ability to inhibit the synthesis of this plant hormone, acetylsalicylic acid (ASA), a synthetic analog of salicylic acid (SA), can be used for preserving floral stems (Moura, Mapeli, Finger, \& Barbosa, 2010).

Souza, Nobre, Gheyi, Dias and Soares (2016) were able to reduce the wilting of the mountain guava (Acca sellowiana Berg) flower, and maintain its color for a longer period, with the use of SA, compared to the control. In lisianthus, SA prolonged the post-harvest quality of flowers by inhibiting the enzymes that alter the color and turgidity of flowers (Bahrami, Zakizadeh, Hamidoghli, \& Ghasemnezhad, 2013). However, in sunflower, no studies are available regarding the use of ASA or SA in enhancing the post-harvest shelf-life.

Further studies about the effect of SA or its analog ASA are needed, mainly on the flowers of greater ornamental importance to exploit the benefits it provides in their postharvest conservation. The present study is designed to evaluate the effect of the of ASA solution on the post-harvest longevity of ornamental sunflower.

\section{Materials and Methods}

The work was conducted in the Phytotechnics Laboratory at the State University of Londrina, Londrina-PR. The floral stems of the ornamental sunflower cultivar Vicent's Choice - Sakata Seed were purchased from a local producer. The stems were selected according to their phenological stage, aiming to use only those in the stage R5.5 (50\% of the flowers in a disc are open) (Castiglioni, Balla, Castro, \& Silveira, 1997). The stem was cut at a standard length of $50 \mathrm{~cm}$ in a bevel, and three leaves were kept below the head.

After this, the inflorescences were placed in a flask containing $350 \mathrm{~mL}$ of a solution containing 200, 400, 600, 800, and $1000 \mathrm{mg}$ of ASA per liter of distilled water, while the control had no ASA. Aspirin ${ }^{\circledR}$ tablets were used as the source of ASA. The solution was changed when it turned cloudy. Ten replicates per treatment were used, one rod per repetition, at $25^{\circ} \mathrm{C}$ under natural lighting.

Floral stems were assigned grades from 0 to 5 every day, based on their quality, as per the senescence table established by Curti, Martin, Ferronato and Benini (2012), with a score of 5 for excellent general appearance, open and bright flowers, 4 for good overall appearance, with open, bright flowers, but with slight wilting of the stem, 3 at the beginning of deterioration, with flowers of radius facing downwards and less bright, 2 when the flowers of radius were withered and curled, stems were discolored and wilted, and 1 when the stems were completely drooped, flower of radius and 
the open disk withered, and score 0 for the totally deteriorated flowers.

The total longevity, defined as the number of days that the inflorescences took to reach the score zero, and the commercial longevity, being the possible limit of commercialization, defined as the number of days that the inflorescences maintained a score equal to or higher than grade 3 , were determined.

Longevity data were evaluated by analysis of variance (ANOVA), Tukey's test ( $t$ $=0.05 \%)$, and regression analysis with Sisvar program.

\section{Results and Discussion}

Through the analysis of variance, it was verified that the time and dose interaction was significant $(p<0.05)$ for the score variable assigned to the flowers. Effect of time for each dose and that of the different doses for each day were evaluated (Table 1).

Over time, a downward trend was observed in the scores assigned to the repetitions for all the doses tested, as a result of the natural senescence of the flower stems (Figure 1). However, while analyzing the effects of doses for each day in question, significant differences were observed from the sixth to the tenth day of evaluation, with the dose of $400 \mathrm{mg}$ $\mathrm{L}^{-1}$ scoring higher averages during this period. This indicates a delay in the senescence of the flower stems, and maintenance of superior quality for longer than any other treatment. Interestingly, scores of the highest dose of $1000 \mathrm{mg} \mathrm{L}^{-1}$ from the eighth day of evaluation, and those of the controls were comparable and were the lowest average scores (Table 2).

There were no significant differences between different treatments in terms of the total longevity of the flowers. However, treatment with $400 \mathrm{mg} \mathrm{L}^{-1}$ dose was able to achieve an average of 9 days of commercial longevity, while the controls had only 5 to 6 days of commercial viability. The treatments with $200 \mathrm{mg} \mathrm{L}^{-1}, 600 \mathrm{mg} \mathrm{L}^{-1}, 800 \mathrm{mg} \mathrm{L}^{-1}$, and $1000 \mathrm{mg} \mathrm{L}^{-1}$ resulted in an average of $6.4,6.2$ 6.6 , and 5.8 days of commercial longevity respectively (Table 3 ). Curiously, the maximum dose of $1000 \mathrm{mg} \mathrm{L}^{-1}$ was no better than the control in extending the commercial lifespan. 
Table 1

Analysis of variance and interaction between doses of acetylsalicylic acid $\left(0 \mathrm{mg} \mathrm{L}^{-1}, 200 \mathrm{mg} \mathrm{L}^{-1}, 400 \mathrm{mg}\right.$ $\mathrm{L}^{-1}, 600 \mathrm{mg} \mathrm{L}^{-1}, 800 \mathrm{mg} \mathrm{L}^{-1}$, and $1000 \mathrm{mg} \mathrm{L}^{-1}$ ) and time ( 0 to 13 days) on the post-harvest quality score of floral stems of Vicent's Choice - Sakata Seed sunflower, treated with a solution of acetylsalicylic acid

\begin{tabular}{|c|c|c|}
\hline \multirow{2}{*}{ Variation source } & \multirow{2}{*}{$\mathrm{DF}^{* *}$} & \multirow{2}{*}{$\begin{array}{c}\text { Mean Square } \\
\text { Score }\end{array}$} \\
\hline & & \\
\hline Time & 13 & $103,6^{*}$ \\
\hline Doses & 5 & $7,1^{*}$ \\
\hline$T \times D$ & 65 & $0,6^{*}$ \\
\hline Time $x$ Doses 0 & 13 & 18,4 * \\
\hline Time x Doses 200 & 13 & 18,8 * \\
\hline Time $x$ Doses 400 & 13 & 14,6 * \\
\hline Time $\times$ Doses 600 & 13 & 15,6 * \\
\hline Time x Doses 800 & 13 & 17,1 * \\
\hline Time x Doses 1000 & 13 & 22,0 * \\
\hline \multicolumn{3}{|l|}{$\mathrm{D} \times \mathrm{T}$} \\
\hline Doses $x$ Time 0 & 5 & 0,0 \\
\hline Doses $\times$ Time 1 & 5 & 0,1 \\
\hline Doses x Time 2 & 5 & 0,2 \\
\hline Doses $x$ Time 3 & 5 & 0,3 \\
\hline Doses x Time 4 & 5 & 0,6 \\
\hline Doses $\times$ Time 5 & 5 & 0,6 \\
\hline Doses $\times$ Time 6 & 5 & $1,7^{*}$ \\
\hline Doses x Time 7 & 5 & 1,8 * \\
\hline Doses x Time 8 & 5 & 2,8 * \\
\hline Doses $x$ Time 9 & 5 & 3,2 * \\
\hline Doses x Time 10 & 5 & $2,3^{*}$ \\
\hline Doses x Time 11 & 5 & 1,3 \\
\hline Doses x Time 12 & 5 & 0,1 \\
\hline Doses x Time 13 & 5 & 0,0 \\
\hline Residual & & 0,47 \\
\hline CV \% & & 26,68 \\
\hline General average & & 2,57 \\
\hline
\end{tabular}

* Analysis of variance was performed at a significance level of $5 \%$.

** Degree of freedom. 
The improvement of the commercial longevity of ornamental sunflower may be because of the ability of SA to inhibit the biosynthesis of ethylene, the hormone responsible for plant senescence (Finger et al., 2004).

Ethylene biosynthesis begins when the enzyme AdoMet synthase produces S-adenosylmethionine from methionine, which in turn is converted into 1-aminocyclopropane1-carboxylic acid (ACC) by ACC synthase. This is ultimately processed into ethylene by ACC oxidase. Salicylic acid blocks the production of ethylene by altering the activity of ACC oxidase (Van Altvorst \& Bovy, 1995). Because of this, the respiration rate also reduces, and with it, the plant senescence (Asghari \& Aghdam, 2010). This aspect is important, because when a high respiratory rat20e causes water loss, greater metabolic activity, and higher consumption of reserve carbohydrates that are necessary for floral opening (Reid, 2002). Previous studies have reported that treatment with $A S$ reduces breathing in fruits, such as bananas (Srivastava \& Dwivedi, 2000) and apples (Mo et al., 2008), which increases their post-harvest longevity.

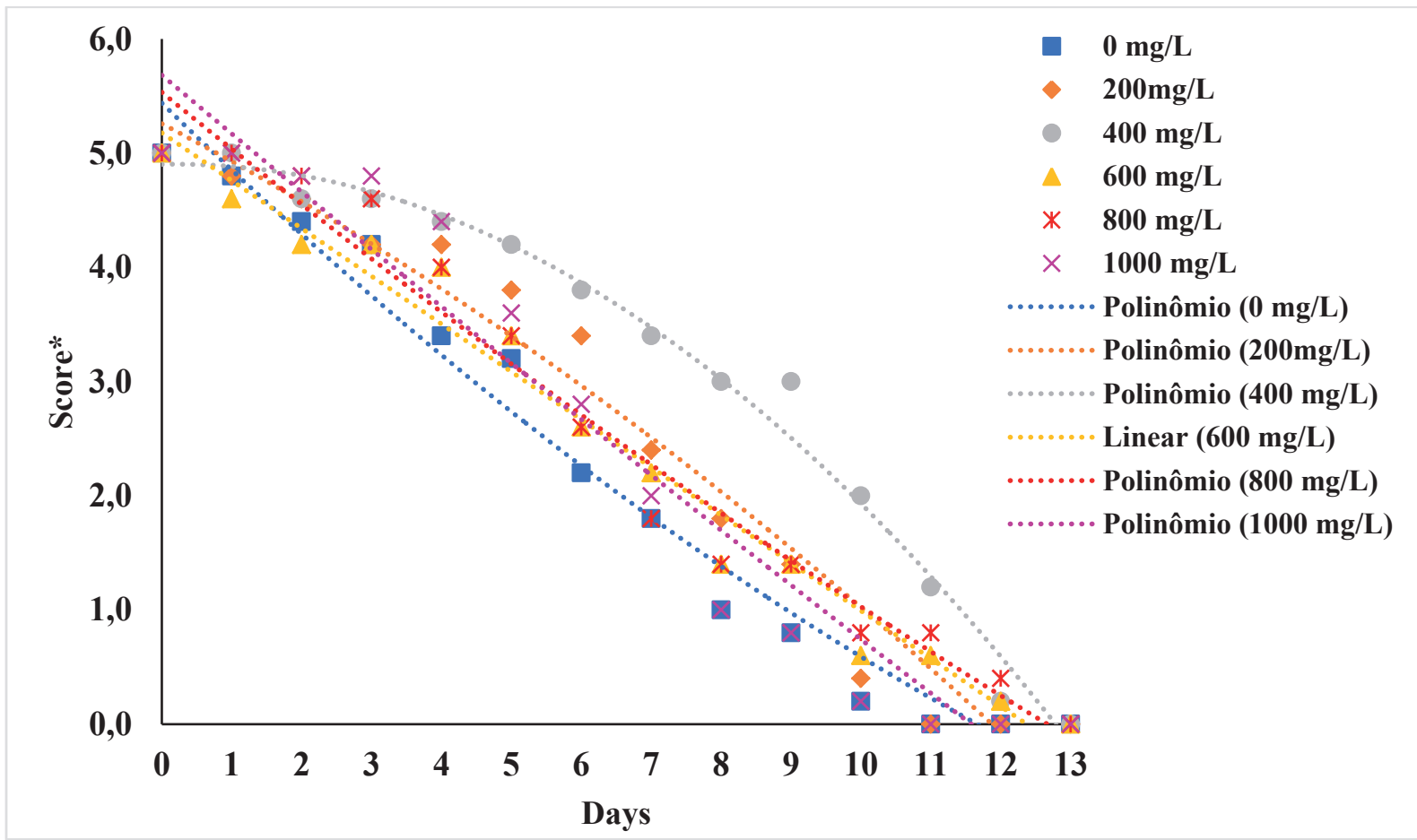

Figure 1. Interaction between dose and time for the post-harvest quality score of floral stems of Vicent's Choice - Sakata Seed sunflower, treated with acetylsalicylic acid solution

Display equation and $R$ - squared: $0 \mathrm{mg}: \mathrm{y}=0,0111 \times 2-0,5961 \mathrm{x}+5,4379 \mathrm{R}^{2}=\mathrm{R}^{2}=0,9742 ; 200 \mathrm{mg}$ : $y=-0,0103 x 2-0,3206 x+5,2579 R^{2}=0,9648 ; 400 m g: y=-0,031 \times 2+0,0132 x+4,9014 R^{2}=R^{2}=$ 0,$9863 ; 600$ mg: $y=-0,4185 x+5,1771 R^{2}=0,9775 ; 800 m g: y=0,0051 \times 2-0,5012 x+5,5321 R^{2}=$ 0,9688; 1000 mg: $y=0,0021 x 2-0,5147 x+5,6821 R^{2}=0,9438$.

* Daily score of quality of the floral rush according to the senescence table by Curti et al, (2012). 


\section{Table 2}

Average grades assigned to post-harvest quality of floral stems of Vicent's Choice - Sakata Seed sunflower, treated with a solution of acetylsalicylic acid over 13 days

\begin{tabular}{|c|c|c|c|c|c|c|c|c|}
\hline \multirow{2}{*}{$\begin{array}{c}\text { Treatment }\left(\mathrm{mg} \mathrm{L}^{-1}\right) \\
\text { Days }\end{array}$} & 0 & 200 & 400 & 600 & 800 & 1000 & \multirow{2}{*}{ CV\% } & \multirow{2}{*}{$\begin{array}{l}\text { General } \\
\text { Average }\end{array}$} \\
\hline & \multicolumn{6}{|c|}{ Score ${ }^{* *}$} & & \\
\hline 0 & $5,0 \mathrm{a}$ & $5,0 a$ & $5,0 a$ & $5,0 a$ & $5,0 a$ & $5,0 a$ & 0 & 5,0 \\
\hline 1 & $4,8 a$ & $4,8 a$ & $5,0 a$ & $4,6 a$ & 5,0 a & $5,0 a$ & 3,35 & 4,9 \\
\hline 2 & $4,4 a$ & $4,6 a$ & $4,6 a$ & $4,2 a$ & $4,8 a$ & $4,8 a$ & 5,59 & 4,6 \\
\hline 3 & $4,2 a$ & $4,2 a$ & $4,6 a$ & $4,2 a$ & $4,6 a$ & $4,8 a$ & 5,99 & 4,4 \\
\hline 4 & $3,4 a$ & $4,2 a$ & $4,4 a$ & $4,0 a$ & $4,0 a$ & $4,4 a$ & 9,15 & 4,1 \\
\hline 5 & $3,2 a$ & $3,8 a$ & $4,2 a$ & $3,4 a$ & $3,4 a$ & $3,6 a$ & 9,93 & 3,6 \\
\hline 6 & $2,2 b$ & $3,4 a b$ & $3,8 a$ & $2,6 a b$ & $2,6 a b$ & $2,8 a b$ & 20,34 & 2,9 \\
\hline 7 & $1,8 b$ & $2,4 a b$ & $3,4 a$ & $2,2 a b$ & $1,8 \mathrm{~b}$ & $2,0 \mathrm{~b}$ & 26,56 & 2,3 \\
\hline 8 & $1,0 \mathrm{~b}$ & $1,8 a b$ & $3,0 \mathrm{a}$ & $1,4 b$ & $1,4 \mathrm{~b}$ & $1,0 \mathrm{~b}$ & 46,77 & 1,6 \\
\hline 9 & $0,8 b$ & $1,4 \mathrm{~b}$ & $3,0 \mathrm{a}$ & $1,4 \mathrm{~b}$ & $1,4 \mathrm{~b}$ & $0,8 \mathrm{~b}$ & 54,99 & 1,5 \\
\hline 10 & $0,2 b$ & $0,4 b$ & $2,0 \mathrm{a}$ & $0,6 b$ & $0,8 a b$ & $0,2 b$ & 96,89 & 0,7 \\
\hline 11 & $0,0 \mathrm{a}$ & $0,0 a$ & $1,2 a$ & $0,6 a$ & $0,8 a$ & $0,0 \mathrm{a}$ & 118,27 & 0,4 \\
\hline 12 & $0,0 \mathrm{a}$ & $0,0 a$ & $0,2 a$ & $0,2 \mathrm{a}$ & $0,4 a$ & $0,0 a$ & 122,47 & 0,1 \\
\hline 13 & $0,0 a$ & $0,0 a$ & $0,0 a$ & $0,0 a$ & $0,0 a$ & $0,0 \mathrm{a}$ & 0 & 0,0 \\
\hline
\end{tabular}

*Averages followed by the same letter on the line do not differ from each other according to the Tukey's test (5\%).

** Daily score of quality of the floral stems according to the senescence table established by Curti et al. (2012).

\section{Table 3}

Commercial longevity and total longevity of floral stems of Vicent's Choice - Sakata Seed sunflower, treated with acetylsalicylic acid solution

\begin{tabular}{|ccc|}
\hline Treatment & $\begin{array}{c}\text { Commercial Longevity } \\
\text { (number of days) }\end{array}$ & $\begin{array}{c}\text { Total Longevity } \\
\text { (number of days) }\end{array}$ \\
\hline $0\left(\mathrm{mg} \mathrm{L}^{-1}\right)$ & $5,6 \mathrm{~b}$ & $9,0 \mathrm{a}$ \\
\hline $200\left(\mathrm{mg} \mathrm{L}^{-1}\right)$ & $6,4 \mathrm{ab}$ & $10,4 \mathrm{a}$ \\
\hline $400\left(\mathrm{mg} \mathrm{L}^{-1}\right)$ & $9,0 \mathrm{a}$ & $12,2 \mathrm{a}$ \\
\hline $600\left(\mathrm{mg} \mathrm{L}^{-1}\right)$ & $6,2 \mathrm{ab}$ & $10,4 \mathrm{a}$ \\
\hline $800\left(\mathrm{mg} \mathrm{L}^{-1}\right)$ & $6,6 \mathrm{ab}$ & $10,2 \mathrm{a}$ \\
\hline $1000\left(\mathrm{mg} \mathrm{L}^{-1}\right)$ & $5,8 \mathrm{~b}$ & $9,6 \mathrm{a}$ \\
\hline Residual & 2,13 & 3,13 \\
\hline $\mathrm{CV} \%$ & 22,13 & 17,19 \\
\hline
\end{tabular}

*Averages followed by the same letter in the column do not differ from each other according to the Tukey's test (5\%). 
According to Chun, Vattem, Lin and Shetty (2005) and Soares (2002), SA, a phenolic compound, is an antioxidant, which can sequester and neutralize the free radicals. In addition, by activating the antioxidant enzymes that remove reactive oxygen species produced due to oxidative stress, SA helps in maintaining cellular metabolism (Xu \& Tian, 2008; Tian, Qin, Li, Wang, \& Meng, 2007).

In lisianthus flowers, Bahrami et al (2013) observed an improved longevity and postharvest quality of stems treated with ASA, due to the reduced activity of lipoxygenase enzymes. The same was observed by Zhang, Chen, Zhang and Ferguson (2003) in kiwi fruits. These authors suggest that SA can restrict the degradation of cell membrane and consequent senescence of plant tissue by reducing free radicals. Srivastava and Dwivedi (2000) also observed a reduction in cellulase and xylanase, the main enzymes that degrade cell wall, and lower levels of peroxidase and catalase, the antioxidant enzymes, in bananas treated with SA.

When the flower stems are cut, the injuries are prone to infections by pathogens, and this can affect the quality and longevity of the produce. Another factor that may help the delay of senescence of ornamental sunflower is the ability of SA to induce systemic resistance in plants. According to Gozzo (2004) and Ding and Wang (2003), endogenous SA is an organic regulator that can be considered as a phytohormone and it induces systemic resistance against agents ranging from pathogens, to abiotic stresses such as high temperature. Therefore, treatment of plants with exogenous chemicals that have a function similar to SA, or the induction of endogenous synthesis of SA itself serves as a strategy to prolong post-harvest life.
Despite the positive effects of applying SAand ASA to maintain the quality and longevity of flowers and fruits, caution is necessary against their use in excess, as this can cause phytotoxicity or promote senescence. Ferreira and Pasin (2014) observed that, treating with $4 \mathrm{~g} \mathrm{~L}^{-1}$ of ASA accelerated the deterioration of floral stems of roses, reducing the time available for their marketing.

\section{Conclusion}

At a dose of $400 \mathrm{mg} \mathrm{L}^{-1}$, ASA prolongs the commercial longevity and maintains the post-harvest quality of ornamental sunflower. For producers and traders in the floriculture sector, this represents an increase in "shelf life", and extension of duration to which the product maintains the quality needed for its marketing.

\section{Acknowledgments}

The authors would like to thank the Coordination for the Improvement of Higher Education Personnel (CAPES) and the National Council for Scientific and Technological Development (CNPq) for the necessary funding for this research.

\section{References}

Albuquerque, M. C. F. E., Moro, F. V., Fagioli, M., \& Ribeiro, M. C. (2001). Testes de condutividade elétrica e de lixiviação de potássio na avaliação da qualidade fisiológica de sementes de girassol. Revista Brasileira de Sementes, 23(1), 1-8. doi: 10.17801/0101-3122/rbs.v23n1p1-8 
Asghari, M., \& Aghdam, M. S. (2010). Impact of salicylic acid on post-harvest physiology of horticultural crops. Trends in Food Science \& Technology, 21(10), 502-509. doi: 10.1016/j.tifs.2010.07.009

Bahrami, S. N., Zakizadeh, H., Hamidoghli, Y., \& Ghasemnezhad, M. (2013). Salicylic acid retards petal senescence in cut lisianthus (Eustoma grandiflorum 'Miarichi Grand White') flowers. Horticulture, Environment, and Biotechnology, 54(6), 519-523. doi: 10.1007/s13580-013-1058

Castiglioni, C. B. R., Balla, A., Castro, C., \& Silveira, J. M. (1997). Fases de desenvolvimento da planta de girassol. EMBRAPA. Recuperado de https://www.infoteca.cnptia.embrapa. br/bitstream/doc/445797/1/doc059.pdf

Chun, S. S., Vattem, D. A., Lin, Y. T., \& Shetty, K. (2005). Phenolic antioxidants from clonal oregano (Origanum vulgare) with antimicrobial activity against Helicobacter pylori. Process Biochemistry, 40(2), 809816. doi: 10.1016/j.procbio.2004.02.018

Curti, G. L., Martin, T., Ferronato, M. L., \& Benini, G. (2012). Girassol ornamental: caracterização, pós-colheita e escala de senescência. Revista de Ciência Agrárias, 35(1), 240-250. doi: 10.19084/rca.16179

Ding, C. K., \& Wang, C. Y. (2003). The dual effects of methyl salicylate on ripening and expression of ethylene biosynthetic genes in tomato fruit. Plant Science, 164(4), 589-596. doi: 10.1016/S0168-94 52(03)00010-4

Dukovisk, D., Bernatzky, R., \& Han, S. (2006). Florewing induction of Guzmania by ethylene. Scientia Horticulturae, 110(1), 104-108. doi: 10.1016/j.scienta. 2006.05.004
Ferreira, M. C., \& Pasin, L. A. A. P. (2014). Análise de métodos de conservação pós-colheita de rosas. Revista Científica da FEPI-Revista Científic@ Universitas, 1-3. Recuperado de http://revista.fepi.br/ revista/index.php/ revista/article/viewFile/210/93

Finger, F. L., Carneiro, T. F., \& Barbosa, J. G. (2004). Senescência pós-colheita de inflorescências de esporinha (Consolida ajacis). Pesquisa Agropecuária Brasileira, 39(6), 533-537. doi: 10.1590/S0100-204X 2004000600003

Freddo, Á. R., Cechim, F. E., \& Mazaro, S. M. (2013). Conservation of yost-harvest leaves of green onion (Allium fistulosum L.) with the use of salicylic acid solution. Applied Research \& Agrotechnology, 6(3), 87-94. doi: 10.5935/PAeT.V6.N3.10

Gozzo, F. (2004). Systemic acquired resistance in crop protection. Outlooks on Pest Management, 15(1), 20. doi: 10. 1564/15feb10

Instituto Brasileiro de Floricultura (2018). 7 Bilhões é o tamanho do mercado das flores no Brasil. Campinas: IBRAFLOR. Recuperado de https://www.ibraflor. com.br/blog-ibraflor/7-bilh\%C3\%B5es\%C3\%A9-otamanho-do-mercado-dasflores-no-brasil.

Mattiuz, C. F. M. (2005). Efeito de agentes químicos na conservação pós-colheita de inflorescências de Alpinia purúrata (Veill) K. Schum. Revista Brasileira de Horticultura Ornamental, 11(1), 35-42. doi: 10.14295/rbho.v11i1.8

Mo, Y., Gong, D., Liang, G., Han, R., Xie, J., \& Li, W. (2008). Enhanced preservation effects of sugar apple fruits by salicylic acid treatment during post-harvest 
storage. Journal of the Science of Food and Agriculture, 88(15), 2693-2699. doi: 10.1002/jsfa.3395

Moura, M. A. de, Mapeli, A. M., Finger, F. L., \& Barbosa, J. G. (2010). Vida de vaso de inflorescências de Epidendrum ibaguense Kunth tratadas com inibidores de etileno. Ornamental Horticulture, 16(2), 146-152. doi: 10.14295/rbho.v16i2.555

Oliveira, M. L. A. (2017). Crescimento e produção de girassol ornamental irrigado com diferentes lâminas e diluições de água residuária. Irriga, 22(2), 204-219. doi: 10.15809/irriga.2017v22n1p204-219

Porat, R., Shlomo, E., Serek, M., Sisler, E. C., \& Borochov, A. (1995). 1-Methylcyclopropene inhibits ethylene action in cut phlox flowers. Postharvest Biology and Technology, 6(3-4), 313-319. doi: 10.1016/0925-5214(95)00014-W

Reid, M. S. (2002). Postharvest handling systems: ornamental crops. Postharvest Technology of Horticultural Crops, (3311), 315-325.

Schoellhorn, R., Ermino, E., \& Alvarez, E. (2003). Specialty cut flower production guides for Florida: Sunflower. Gainesville: Institute of Food and Agricultural Sciences, University of Florida. Retrieved from https://ufdcimages.uflib.ufl.edu/ IR/00/00/17/51/00001/EP14200.pdf

Silva, L. R. da, \& Silva, S. Melo de. (2010). Armazenamento de crisântemos brancos sob condição ambiente utilizando soluções conservantes. Semina: Ciências Agrárias, 31(1), 85-92.
Soares, S. E. (2002). Phenolic acids as antioxidants. Revista de Nutrição, 15(1), 71-81. doi: 10.1590/S1415-527320020 00100008

Souza, R. M., Nobre, R. G., Gheyi, H. R., Dias, N. S., \& Soares, F. A. L. (2010). Utilização de água residuária e de adubação orgânica no cultivo do girassol. Revista Caatinga, 23(2), 125-133.

Srivastava, M. K., \& Dwivedi, U. N. (2000). Delayed ripening of banana fruit by salicylic acid. Plant Science, 158(1-2), 8796. doi: 10.1016/S0168-9452(00)00304-6

Tian, S., Qin, G., Li, B., Wang, Q., \& Meng, X. (2007). Effects of salicylic acid on disease resistance and postharvest decay control of fruits. Stewart Postharvest Rev, 6(2), 1-7. doi: 10.2212/spr.2007.6.2

Van Altvorst, A. C., \& Bovy, A. G. (1995). The role of ethylene in the senescence of carnation flowers, a review. Plant Growth Regulation, 16(1), 43-53. doi: 10.1007/BF00040506

Xu, X., \& Tian, S. (2008). Salicylic acid alleviated pathogen-induced oxidative stress in harvested sweet cherry fruit. Postharvest Biology and Technology, 49(3), 379-385. doi: 10.1016/j.postharvbio.2008.02. 003

Zobiole, L. H. S., Castro, C., Oliveira, F. A., \& Oliveira, A., Jr. (2010). Marcha de absorção de macronutrientes na cultura do girassol. Revista Brasileira de Ciência do Solo, 34(2), 425-433. doi: 10.1590/S0100-068 32010000200016

Zhang, Y., Chen, K., Zhang, S., \& Ferguson, I. (2003). The role of salicylic acid in postharvest ripening of kiwifruit. Postharvest Biology and Technology, 28(1), 67-74. doi: 10.1016/S0925-5214 (02)00172-2 